\title{
ANALISIS KEMAMPUAN KOGNITIF PESERTA DIDIK DALAM MENYELESAIKAN SOAL MOMENTUM DAN IMPULS
}

\author{
${ }^{1}$ Nabilah, M , ${ }^{2}$ Stepanus, S. S, ${ }^{3}$ Hamdani \\ 1,2,3 Prodi Pendidikan Fisika, Universitas Tanjungpura, Kota Pontianak, Indonesia \\ *Email korespodensi: monanabilah1324@gmail.com
}

\section{INFO ARTIKEL}

Diterima 00 Juni 2020

Dipublikasikan 00 Agustus 2020

\begin{abstract}
This research aims to examine students' cognitive abilities in completing physics problem about momentum and impulses at SMA Kristen Immanuel Pontianak. The research uses survey method, by giving test that consists of $11^{\text {th }}$ grader ( 53 male; 69 female). According to the result, it was found that the total average percentage of students' cognitive abilities in general (C1-C4) was 69\% and was categorized as medium. The highest average percentage of student cognitive ability was in the domain remembering (C1) with the percentage of $90 \%$ (high) and the lowest was in the domain of analyzing with the percentage of 53\% (low). Furthermore, there was difference in students' cognitive ability based on gender in domain of remembering (C1), that was recognized from the result of Mann-Whitney statistical test $(0.004<0.05)$, which showed that significance value was below the probability value. This research is expected to be a guide and reference in developing learning strategies in physics problem to improve students' cognitive abilities.
\end{abstract}

Kata Kunci: Analysis, Cognitive, Momentum and Impulses, Gender

\section{Pendahuluan}

Proses pembelajaran disekolah menempatkan peserta didik sebagai komponen yang menentukan keberhasilan pencapaian tujuan dalam proses belajar. Belajar merupakan suatu proses untuk mencapai tujuan, atau sebagai proses perubahan dan meningkatkan kemampuan kognitif, afektif, dan psikomotorik (Suhaida, 2018). Hasil survei Programme for International Student Assessment (PISA) tahun 2015 menunjukkan kemampuan peserta didik di Indonesia secara berturut-turut untuk kemampuan sains, memba ca dan matematika masih rendah, yaitu berada pada peringkat 62, 61 dan 63 dari 69 negara yang dievaluasi (Kemendikbud, 2018). Selain itu, hasil survei tahun 2015 yang dilakukan pada peserta didik yang berumur 15 tahun dalam bidang sains, Indonesia memperoleh skor 403. Skor tersebut tergolong rendah, sebab masih berada di bawah rata-rata skor seluruh negara partisipan Organisation for Econimic Co-operation and Development (OECD) yaitu 493 (PISA result, 2016). Hal ini dikarenakan soal yang digunakan pada PISA mencakup aspek kognitif enam tingkat proses kognitif (Aida, 2017). Sehingga dapat disimpulkan bahwa kemampuan kognitif peserta didik Indonesia masih berada di bawah rata-rata negara-negara OECD.

Salah satu upaya yang telah dilakukan pemerintah terkait rendahnya aspek kognitif siswa yaitu dengan menerapkan kurikulum yang diharapkan bisa meningkatkan kualitas pendidikan di Indonesia yaitu kurikulum 2013. Menurut Syaiful (2018) kurikulum 2013 dirancang untuk meningkatkan kinerja yang berkualitas tinggi melalui proses pembelajaran sehingga menciptakan kemampuan peserta didik yang memiliki kualitas tinggi. Kurikulum 2013 mengadaptasi model-model penilaian standar Internasional yang diharapkan dapat membatu peserta didik dalam meningkatkan kemampauan berpikir yang mana kurikulum tersebut mererapkan pendekatan saintifik yang dapat mendukung kreatifitas peserta didik (Gais, 2017). Dalam pembelajaran kurikulum 2013 terdapat salah satu penilaian yaitu penilaian aspek kognitif, yang mana dapat mengukur kemampuan kognitif peserta didik selama pembelajaran (Aini, 2016).

Menurut Vidayanti (2017) kemampuan kognitif merupakan kemampuan yang mampu meningkatkan kemampuan berpikir peserta didik. Salah satu teori yang membahas pentingnya kemampuan kognitif adalah teori 
yang dikemukakan oleh Benyamin S. Bloom, kualitas pendidikan yang baik diperoleh dengan menerapkan semua tingkat ranah kognitif dalam setiap pembelajaran (Huda, 2013). Kemampuan kognitif merupakan penguasaan peserta didik dalam ranah kognitif. Ranah kognitif berisi perilaku yang menekankan aspek intelektual, seperti pengetahuan, dan keterampilan berpikir yang mencakup kemampuan berpikir tingkat rendah atau Lower Order Thinking Skills (LOTS) mengingat (C1), memahami (C2), dan mengaplikasikan (C3), lalu ada tiga aspek dari kemapuan berpikir tingkat tinggi Higher Order Thinking Skills (HOTS) yaitu kemampuan menganalisis (C4), mengevaluasi (C5) dan mencipta (C6) berdasarkan taksonomi Bloom yang telah direvisi (Anderson dan Krathwohl, 2002).

Hardianti (2018) menyatakan bahwa pentingnya menganalisis kemampuan kognitif peserta didik yaitu untuk mengetahui pencapaian hasil belajar dan level pencapaian kemampuan kognitif peserta didik. Dengan dilakukannya analisis kemampuan kognitif diharapkan dapat membantu guru mengetahui sejauh mana level kemampuan kognitif dan mengetahui seberapa tinggi pencapaian yang telah dicapai peserta didik. Selain itu untuk memudahkan guru memperbaiki pola pikir peserta didik dalam menemukan solusi, serta untuk mencapai kemampuan kognitif peserta didik secara maksimal. Sehingga, diharapkan dapat meningkatkan kualitas peserta didik. Untuk meningkatan kualitas peserta didik guru dapat merancang pembelajaran di dalam kelas yang mengarah pada meningkatkan kemampuan kognitif. Rancangan pembelajaran yang dibuat berdasarkan hasil analisis kognitif tersebut, merupakan upaya untuk peningkatan kualitas pembelajaran peserta didik yang mana pada akhirnya dapat meningkatkan kualitas lulusan.

Menurut Rosa (2015) kemampuan kognitif peserta didik dapat dikur dengan memberikan tes kepada peserta didik. Ini berguna untuk mendapatkan informasi yang dibutuhkan dalam proses pembelajaran. Untuk mengetahui kemampuan kognitif peserta didik maka pemerintah beberapa tahun belakangan ini mengadakan ujian nasioanal dengan menerapkan ranah kognitif yang tidak hanya pada tingkatan berpikir yang rendah, tetapi juga pada berpikir tingkat tinggi. Menurut Yuliani (2019) dengan diberlakukannya kemampuan berpikir tingkat tinggi tersebut secara umum menjadi salah satu penyebab terjadinya penurunan rata-rata nilai ujian nasional, terutama pada mata pelajaran matematika, fisika dan kimia, yang mana terdapat soal-soal penalaran sekitar 10-15\%, yakni terdapat 4-5 butir soal dari total semua soal. Berdasarkan data Kemendikbud (2018) rata-rata hasil ujian nasional di Kota Pontianak pada program studi IPA selama 2 tahun ini yaitu pada tahun 2016-2017 adalah 62.05 dan 51.63. Adapun hasil rata-rata ujian nasional pada mata pelajaran fisika sebesar 64.28 pada tahun 2016 dan 44.90 di tahun 2017. Dari data tersebut dapat diketahui bahwa terjadi penuruan di mata pelajaran fisika di Kota Pontianak.

Adapun salah satu materi fisika yang menjadi kisi-kisi pada ujian nasional yaitu materi momentum dan impuls. Berdasarkan Kemendikbud (2018) pada kisi-kisi ujian nasional SMA tahun 2017/2018 level kognitif materi momentum dan implus yang diujikan berada pada level kognitif pengetahuan, pemahaman, aplikasi, dan penalaran. Menurut Khasyyatillah (2016) untuk menyelesaikan permasalahan yang ada pada materi momentum dan impuls tidak cukup hanya dengan mengandalkan kemampuan mengingat dan menghapal rumus-rumus. Hal ini ditunjukkan dalam penelitian Agustin, Yuliati dan Zulaikah (2017) yang menyatakan bahwa 17 dari 34 peserta didik mengalami kesalahan dalam pemecahan masalah pada konsep momentum, 29 peserta didik mengalami kesalahan dalam menyelesaikan masalah pada konsep impuls, 26 peserta didik mengalami kesalahan dalam konsep permasalahan hukum kekekalan momentum, dan 24 peserta didik mengalami kesalahan dalam pemecahan masalah pada konsep tumbukan. Dari data tersebut dapat diketahui bahwa banyak kesalahan konsep yang dialami peserta didik. Peserta didik dapat dikatakan menguasai sebuah kosep pembelajaran, apabila mampu melakukan proses mental yang disebut proses kognitif. Menurut Susana (2015) proses kognitif sering dijadikan sebagai indikator seorang peserta didik menguasai suatu konsep atau tidak dalam pembelajaran. Oleh karena itu, materi momentum dan impuls sangat penting untuk dianalisis, sehingga diharapkan dapat diketahui rancangan pembelajaran yang tepat. Hal ini dikarenakan materi momentum dan impuls merupakan salah satu materi prasyarat untuk mempelajari materi fisika selanjutnya, seperti dinamika rotasi, teori kinetik gas dan relativitas (Sunardi, 2017). 
Selain mendeskripsikan kemampuan kognitif peserta didik, perlu juga untuk menyelidiki kemampuan kognitif peserta didik dari perbedaan gender. Ini dikarenakan perbedaan gender menyebabkan perbedaan secara fisik dan mempengaruhi pola pikir dalam belajar (Amir, 2013). Menurut Hardianti (2018) salah satu penyebab setiap peserta didik memiliki kemampuan kognitif pada tingkatan yang berbeda-beda ialah perbedaan gender. Menutut Rosa (2015) kemampuan peserta didik dalam ranah kognitif dan psikomotorik, peserta didik perempuan lebih tinggi dibandingkan dengan peserta didik laki-laki. Terdapat perbedaan kemampuan pemecahan masalah antara perempuan dan laki-laki, laki-laki lebih unggul dalam penguasaan matematis dan pemecahan masalah dibandingkan dengan perempuan (Helgeson, 2012). Adanya perbedaan gender antara laki-laki dan perempuan dalam beberapa bidang yaitu: 1) laki-laki lebih baik dalam penalaran berpikir, memahami dan memproses sesuatu dalam bentuk visual; 2) laki-laki lebih baik dalam keahlian kuantitatif dan memecahkan masalah; 3) perempuan lebih baik dalam komprehensif verbal, kefasihan bahasa dan komunikasi (Nasution, 2011). Pramawati (2016) menyatakan bahwa terdapat perbedaan yang signifikan antara kemampuan berpikir kritis antara laki-laki dan perempuan, dimana rata-rata kemampuan berpikir kritis peserta didik laki-laki lebih tinggi dibandingkan dengan peserta didik perempuan.

Oleh karena itu penelitian ini dilakukan dengan maksud untuk mengetahui kemampuan kognitif peserta didik dalam menyelesaikan soal materi momentum dan impuls di SMA Kristen Immanuel Kota Pontianak, sehingga diharapkan dapat digunakan sebagai bahan refrensi untuk guru dan peneliti lebih lanjut dalam meningkatkan kemampuan koginitif peserta didik

\section{Metode Penelitian}

Metode yang digunakan dalam penelitian ini yaitu metode peneltian survei. Populasi dalam penelitian ini adalah peserta didik kelas XI SMA Kristen Immanuel Pontianak sebanyak 3 kelas dengan total populasi penelitian sebanyak 122 peserta didik. Pengambilan sampel yang digunakan dalam penelitian ini menggunakan sample size calculator, dengan taraf signifikansi 5\% dan besar tingkat kepercayaan sebesar $95 \%$ diperoleh sampel minimum sebanyak 93 sampel. Teknik pengambilan sampel menggunakan sampling jenuh, sehingga dalam penelitian ini 3 kelas dijadikan sebagai sample dengan total partisipan 122 peserta didik. Instrumen dalam penelitian ini berbentuk uraian sebanyak 8 buah soal tes kemampuan kognitif. Soal disusun berdasarkan indikator kemampuan kognitif yaitu terdiri atas 2 butir soal mengingat (C1), 2 butir soal memahami (C2), 2 butir soal mengaplikasi (C3), dan 2 butir menganalisis (C4).

\section{Hasil dan Pembahasan}

\subsection{Hasil}

Hasil analisis profil kemampuan kognitif peserta didik dalam mengerjakan soal momentum dan impuls dapat dilihat pada Tabel 1.

Tabel 1

Rekapitulasi Jumlah Kemampuan Kognitif Peserta Didik Pada Setiap Ranah Kognitif

\begin{tabular}{cccc}
\hline Ranah Kognitif & Rata-rata & Persentase Kemampuan Kognitif & Level \\
\hline Mengingat (C1) & 0.901 & $90 \%$ & Tinggi \\
\hline Memahami (C2) & 0.725 & $73 \%$ & Sedang \\
\hline Mengaplikasi (C3) & 0.616 & $61 \%$ & Sedang \\
\hline Menganalisis (C4) & 0.533 & $53 \%$ & Rendah \\
\hline Rata-rata & 0.694 & $69 \%$ & Sedang \\
\hline
\end{tabular}

Tabel 1 memperlihatkan kemampuan kognitif peserta didik dengan pencapaian rata-rata persentase 69\% dengan kategori sedang. Rata-rata nilai persentase yang paling tinggi yaitu pada ranah kognitif mengingat (C1) sebesar 90\%, sedangkan rata-rata nilai persentase terendah pada ranah kognitif menganalisis (C4) sebesar 53\%. 
Permasalahan kedua dalam penelitian ini menguji hipotesis signifikasi perbedaan kemampuan kognitif berdasarkan gender. Kemampuan kognitif peserta didik laki-laki dan perempuan ditunjukkan pada Tabel 2.

Tabel 2

Rekapitulasi Kemampuan Kognitif Peserta Berdasarkan Gender

\begin{tabular}{ccccc}
\hline \multirow{2}{*}{ Ranah Kognitif } & \multicolumn{4}{c}{ Persentase Kemampuan Kognitif } \\
\cline { 2 - 5 } & Laki-laki & Level & Perempuan & Level \\
\hline Mengingat (C1) & $83 \%$ & Tinggi & $96 \%$ & Sangat Tinggi \\
\hline Memahami (C2) & $70 \%$ & Sedang & $71 \%$ & Sedang \\
\hline Mengaplikasi (C3) & $62 \%$ & Sedang & $61 \%$ & Sedang \\
\hline Menganalisis (C4) & $53 \%$ & Rendah & $53 \%$ & Rendah \\
\hline Rata-rata & \multicolumn{3}{c}{$67 \%$} \\
\hline
\end{tabular}

Hasil analisis tiap ranah kognitif, mengingat, memahami, mengaplikasi, menganalisis antara laki-laki dan perempuan menunjukkan kemampuan kognitif peserta didik laki-laki dan perempuan tertinggi yaitu pada ranah kognitif mengingat (C1) yaitu sebesar 83\% dan 96\%, data tersebut diperoleh dari 53 peserta didik laki-laki dan 69 peserta didik perempuan. Data yang didapatkan dianalisis menggunakan uji Mann-Whitney dan uji t independent sample dengan menggunakan SPSS. Hasil uji Mann-Whitney dapat dilihat pada Tabel 3. Hasil uji $t$ independent sample dapat dilihat pada Tabel 4.

Tabel 3

Hasil Uji Mann-Whitney Data Kemapuan Kognitif Pada Tiap Ranah Kognitif Berdasarkan Gender

\begin{tabular}{lccc}
\hline & C1 & C2 & Total \\
\hline Mann-Whitney U & 1461.000 & 1690.000 & 1822.000 \\
\hline$Z$ & -2.897 & -.764 & -.036 \\
\hline Asymp. Sig. (2-tailed) & .004 & .445 & .971 \\
\hline
\end{tabular}

a. Grouping Variable: GENDER

Tabel 4

Hasil t independent sample Data Kemapuan Kognitif Pada Tiap Ranah Kognitif Berdasarkan Gender

\begin{tabular}{ccc}
\hline Uji T & $C 3$ & $C 4$ \\
\hline$T$ & .339 & -.200 \\
\hline$D f$ & .20 & 120 \\
\hline Sig(2-tailed) & .735 & .842 \\
\hline Mean difference & .335 & .457 \\
\hline Std, error difference & .986 & 2.289 \\
\hline
\end{tabular}

Hasil analisis uji Mann-Whitney pada ranah C1 yaitu $0.004<0.05$, C2 yaitu $0.445>0.05$, total $0.971>0.05$. Serta hasil uji $t$ independent sample pada ranah C3 yaitu 0.735>0.05, dan C4 yaitu 0.842>0.05. Hal ini menunjukkan bahwa terdapat perbedaan kemampuan kognitif antara laki-laki dan perempuan pada ranah kognitif C1.

\subsection{Pembahasan}

Pada penelitian ini membahas mengenai kemampuan kognitif peserta didik pada ranah kognitif mengingat (C1), memahami (C2), mengaplikasi (C3), menganalisis (C4). Masalah pertama pada penelitian ini mengidentifikasi profil kemampuan kognitif peserta didik dalam menyelesaikan soal pada materi momentum dan impuls. Rata-rata nilai persentase dari keempat ranah kognitif (C1, C2, C3, C4) sebesar 69\% dan dikategorikan sedang. Berdasarkan hasil analisis jawaban peserta didik pada ranah mengingat (C1) rata-rata nilai persentase sebesar 90\% dikategorikan tinggi, hal tersebut menunjukkan bahwa peserta didik mampu mengingat peristiwa yang berkaitan dengan impuls 
dan tumbukan. Pada pengerjaan soal ranah kognitif C1 dapat terjadi kesalahan karena beberapa faktor yaitu peserta didik tidak memahami konsep pada materi momentum impuls dan tumbukan dengan benar, serta peserta didik lupa pada materi dikarenakan materi yang diuji sudah jauh terlewati. Pada ranah kognitif memahami (C2) rata-rata nilai persentase sebesar 73\% kategori sedang. Dari hasil analisis jawaban peserta didik diketahui bahwa terdapat beberapa peserta didik dapat menentukan dan menjelaskan hukum yang berlaku pada tumbukan lenting sempurna dan aplikasi hukum kekekalan momentum dengan tepat. Kekeliruan dalam pengerjaan soal C2 dapat terjadi karena dalam proses pengerjaan soal peserta didik tergesa-gesa dan lupa terhadap materi yang telah dipelajari (Rufaida, 2012), pemberian materi dan pemberian tes memiliki rentang waktu yang cukup lama juga menjadi salah satu faktor penyebab kekeliruan dalam menyelesaikan soal.

Pada ranah kognitif mengaplikasi (C3) rata-rata nilai persentase sebesar 61\% terkategori sedang. Hal ini menunjukkan peserta didik mampu menyelesaikan soal pada ranah C3 mengenai impuls dan hukum kekekalan momentum. Terdapat beberapa kekeliruan peserta didik dalam pengerjaan soal ranah kognitif C3 yaitu kesalahan dalam memahami dan menterjemahkan soal sehingga menyebabkan beberapa peserta didik melewati satu tahapan penyelesaian, kesalalahan dalam menggunakan konsep untuk mengerjakan, dan kesalahan dalam perhitungan menyelesaikan permasalahan. Pada ranah kognitif menganalisis (C4) rata-rata nilai persentase sebesar 53\% terkategori rendah, hal ini dikarenanakan C4 merupakan kemampuan berpikir pada level high order thinking skill. Dapat dilihat dari hasil pengerjaan soal peserta didik kesulitan peserta didik dalam menyelesaikan soal C4 yaitu peserta didik mengalami kekeliruan dalam menerjemahkan soal, kurangnya pemahaman peserta didik dalam menyelesaikan soal dan kesalahan konsep seperti yang terlihat dari jawaban peserta didik yang tidak memahami dan mengaplikasikan persamaan impuls dengan tepat, kesalahan hitung, dan kesalahan strategi dalam menganalisis mengakibatkan peserta didik tidak paham cara mengerjakan soal dengan cara yang benar dan lengkap. Lasry dkk (2009) menyatakan bahwa peserta didik lebih banyak mendapatkan pembelajaran yang bersifat matematis, hal ini menyebakan peserta didik terbiasa mencari rumus yang sesuai untuk digunakan ketika mengerjakan soal daripada menganalisis dengan menggunakan pengetahuan yang mereka miliki. Syaiful (2018) menyatakan bahwa belum terbiasanya peserta didik menggunakan soal-soal berbasis HOTS, dan pembelajaran yang paling sering dilakukan yaitu pada ranah kognitif mengingat (C1), memahami (C2), dan mengapliksai (C3).

Berdasarkan hasil uji Mann-Whitney pada ranah kognitif C1 kemampuan kognitif peserta didik laki-laki dan perempuan nilai signifikansi dibawah nilai probabilitas $(0.004<0.05)$ dari hasil tersebut dapat diketahui bahwa terdapat perbedan kemampuan kognitif. Rosa (2015) menyatakan bahwa kemampuan penyelesaian soal dalam bentuk teori perempuan lebih tinggi dibandingkan dengan laki-laki. Hasil penelitian Parlemo (2015) menunjukkan bahwa perempuan memiliki daya ingat yang baik dan kuat dibandingkan laki-laki, disebabkan karena perempuan terbiasa menjalani pola multitasking dalam kehidupan. Pada ranah kognitif C2, setelah dilakukan analisis statistik dengan menggunakan uji Mann-Whitney menunjukkan nilai signifikansi diatas nilai probabilitas $(0.445>0.05)$. Dengan demikian, hal tersebut menunjukan tidak terdapat perbedaan kemampuan antara laki-laki dan perempuan secara signifikan pada ranah kognitif memahami (C2).

Pada ranah kognitif C3, setelah dilakukan uji statistik $t$ independent sampel untuk melihat perbedaan kemampuan kognitif C3 peserta didik, dapat diketahui bahwa nilai sig yaitu $(0.735>0.05)$ dengan demikian berdasarkan kriteria pengambilan keputusan, dapat disimpulkan pada ranah kognitif mengaplikasi (C3) antara lakilaki dan perempuan tidak terdapat perbedaan kemampuan kognitif secara. Pada ranah kognitif C4 Dari hasil uji statisitik $\mathrm{t}$ independent sampel, diketahui bahwa nilai sig yaitu (0.842>0.05) dengan demikian, berdasarkan kriteria pengambilan keputusan menunjukkan pada ranah kognitif C4 tidak terdapat perbedaan kemampuan antara lakilaki perempuan. Hal ini didukung oleh penelitian Asis dkk (2015) menyatakan bahwa tidak ada perbedaan kemampuan spasial antara peserta didik laki-laki dan perempuan. Dari hasil uji statistik Mann-Whitney untuk mengetahui perbedaan kemampuan kognitif peserta didik laki-laki dan perempuan secara keseluruhan dari empat aspek ranah kogntitif yang diujikan dalam penelitian diperoleh hasil yaitu nilai signifikansi diatas nilai probabilitas (0.971>0.05) hal tersebut menunjukkan bahwa tidak ada perbedaan kemampuan kognitif antara laki-laki dan perempuan dalam menyelesaikan soal pada materi momentum dan impuls. Sejalan dengan penelitian Perawani 
(2019) menyatakan bahwa tidak adanya perbedaan kemampuan antara laki-laki dan perempuan pada dimensi kognitif. Dari beberapa penelitian mengenai gender tidak terdapat perbedaan kemampuan kognitif antara laki-laki dan perempuan (Santrock, 2003). Hal tersebut menunjukkan bahwa kemampauan kognitif peserta didik laki-laki dan perempuan berpotensi sama.

\section{Kesimpulan}

Berdasarkan hasil penelitian, secara umum dapat disimpulkan bahwa kemampuan kognitif peserta didik kelas XI MIPA SMA Kristen Immanuel Pontianak dalam menyelesaikan soal materi momentum dan impuls tergolong sedang dengan rata-rata nilai persentase sebesar $69 \%$. Secara khusus hasil penelitian dapat disimpulkan sebagai berikut: Berdasarkan hasil analisis profil kemampuan kognitif peserta didik sebagai berikut: a) rata-rata nilai persentase ranah kognitif mengingat (C1) sebesar 90\%, b) rata-rata nilai persentase ranah kognitif memahami (C2) sebesar $73 \%$, c) rata-rata nilai persentase ranah kognitif mengaplikasi (C3) sebesar 61\%, dan rata-rata nilai persentase ranah kognitif menganalisis (C4) sebesar 53\%. Terdapat perbedaan kemampuan kognitif laki-laki dan perempuan yaitu pada ranah kognitif $C 1$, hal ini ditunjukkan yaitu pada ranah kognitif $C 1 \quad(0.004<0.05)$, sedangkan pada ranah kognitif C2, C3, C4 tidak terdapat perbedaan. Secara umum tidak terdapat perbedaan kemampuan kognitif antara laki-laki dan perempuan.

\section{Referensi}

Aida, Nur. (2017).Karakteristik Instrumen Penilaian Hasil Belajar Matematika Ranah Kognitif Yang Dikembangkan Mengacu Pada Model PISA. Suska Journal of Mathematics.Vol. 3, No. 2, 2017, Hal. 130 - 139.

Aini, Nur. (2016). Analisis Kemampuan Kognitif Siswa Dalam Evaluasi Pembelajaran Matematika Menggunakan Model Countenace Stake. Skripsi: (Online). (https://diglib.uinsby.ac.id), diakses pada 30 Maret 2019.

Amir, Z. MZ. (2013). Perspektif Gender dalam Pembelajaran Matematika. Marwah: Jurnal Perempuan, Agama, dan Gender12(1), 15-31. DOI: http://dx.doi.org/10.24014/marwah.v12i1.511

Anderson dan Krathwohl. (2002). Revisi Taksonomi Bloom. Jakarta: Rineka Cipta.

Gais, Zakina. (2017). Analisis Kemampuan Siswa Dalam Menyelesaikan Soal HOTS Ditinjau dari Kemampuan Awal Matematis Siswa. Jurnal Maosharafe, Vol 6,No 2, p255-26.

Hardianti, Tuti. (2018). Analisis Kemampuan Peserta Didik Pada Ranah Kognitif dalam Pembelajaran FISIKA SMA. Jurnal Pendidikan Fisika UAD. Seminar Nasional Quantum.

Helgeson, v. S. (2012). The Psychology of Gender 4th ed. United States: Pearson Education Inc, 1-10.

Huda, Miftahul. (2013). Model-model Pengajaran dan Pembelajaran. Yogyakarta: Pustaka Pelajar

Kemendikbud. (2018). Hasil Ujian Untuk perbaikan Kualitas Pendidikan. (online). (https://www.kemdikbud.go.id/main/blog/2018/05/hasil-un-untuk-perbaikan-kualitas-pendidikan) diakses 30 September 2018.

Kemendikbud. (2018). Peringkat Indonesia Pada PISA. (online).

(https://www.kemdikbud.go.id/main/blog/2016/12/peringkat-dan-capaian-pisa-indonesia-mengalamipeningkatan) diakses 30 September 2018

Kemendikbud. (2018). Kisi-Kisi USBN dan UN Tahun Pelajaran 2017/2018.

(online).(https://www.kemdikbud.go.id/main/blog/2017/12/kisikisi-usbn-dan-un-tahun-pelajaran-20172018) diakses 30 September 2018.

Lasry dkk . (2009). Are Most People to Dumb For Physic?. Physic Teach. Diakses tanggal 19 September 2019. Nasution. (2017). Berbagai Pendekatan Dalam Proses Belajar dan Mengajar. Bandung : Bumi Aksara.

Parlemo, Liam. (2015). Women Outperform Men In Remembering to Remember. The Quartery Journal of Experimental Psychology. Diakses tanggal 19 September 2019.

PISA Result. (2016). PISA Result 2015. (online). (https://www.oecd.org/pisa/pisa-2015-results-in-focus.pdf). Diakses 24 April 2019 
Perawani. (2019). Analisis Kemampuan Kognitif Peserta Didik Dalam Menyelesaikan Soal Materi Kalor dan Perpindahannya. Jurnal Pendidikan Fisika FKIP UNTAN. Diakses tanggal 19 September 2019.

Pramawati, N. M. N., Dantes, N., \& Parmiti, D. P. (2016). Pengaruh Model Pembelajaran Kooperatif Tipe Think Pair Share (TPS) Terhadap Keterampilan Berpikir Kreatif Ditinjau Dari Jenis Kelamin Pada Siswa Kelas V. e-Journal PGSD Universitas Pendidikan Ganesha. Vol. 4 No. 1 Hal: 1-10.

Rufaida, Sufi Ani . (2012). Profil Kesalahan Siswa Sma Dalam Pengerjaan Soal Pada Materi Momentum Dan Implus. (Online). (http://www.jurnal,fkip.uns.ac.id/index.php/prosfis 1/download/3746/2629). Diakses tanggal 18 September 2019.

Rosa, Friska Octavia. (2015). Analisis kemampuan Siswa Kelas X Pada Ranah Kognitif, Afektif dan Psikomotorik. Jurnal Fisika dan Pendidikan Fisika, OMEGA. Vol 1 No. 2.

Santrock. John W. (2003). Adolesence Perkembangan Remaja Vol 6. Jakarta: Erlangga.

Suhaida, Dada. (2018). Analisis Kemampuan Siswa Dalam Pembelajaran Pendidikan Kewarganegaraan di Sekolah Menengah Pertama Negeri 2 Siantan Kabupaten Mempawah. Jurnal Pendidikan Kewarganegaraan, Vol 2, No. 2.

Sunardi. (2017). Buku Guru Fisika Untuk SMA/MA Kelas X. Bandung: Yrama Widya.

Susana. (2015). Analisis Didaktis Berdasarkan Kemampuan Kognitif dan Keterampilan Berpikir Kritis Siswa Pada Materi Kalor. Jurnal pengembangan dan pendidikan Fisika. Vol 1, No. 2.

Syaiful, Rochman. (2018). Analisis High Order Thinking Skills (HOTS) Taksonomi Menganalisis Pemecahan Fisika. Science and Physics Education Journal (SPEJ), Vol 1, No 1, pp. 78-88. Diakses tanggal 19 September 2019.

Vidayanti, Nurul. (2017). Analisis Kemampuan Kognitif Siswa Kelas VIII SMP Negeri 11 Jember Ditinjau Dari Gaya Belajar Dalam Mneyelesaikan Soal Pokok Bahasan Lingkaran. Kadikma. Vol. 8, No 1

Yuliani, Anik. (2019). Penyusunan Laporan PTK Guru. Sidoharjo: Uwais Inspirasi Indonesia. 